\title{
Zpráva z TCT 2020
}

\author{
Jan F. Vojáček \\ 1. interní kardioangiologická klinika LF UK a FN Hradec Králové \\ Kardiologie Bulovka, s. r. o., Praha
}

TCT 2020 se konalo ve dnech 14.-18. řijna 2020 virtuálně on-line na platformě TCT Connect v rozsahu ne príliš odlišném od předchozích prezenčních ročníků.

Počet a obsah jednotlivých sekcí a kvalita prezentací a panelistů odpovídala minulým zkušenostem, možnost připojení byla poskytnuta bezplatně všem zájemcům z řad intervenčních kardiologů z celého světa.

Z celé raady velmi zajímavých sekcí bych chtěl informovat hned o jednom z prvních bloků věnovanému velmi aktuálnímu tématu: "Interventional Cardiology in the era of COVID-19".

Téměř dvouhodinovému bloku Interventional Cardiology in the era of COVID-19, COVID-19 cardiovascular complications predsedal Sahil A. Parikh z Columbia Presbyterian Hospital New York city, spolupředsedající Timothy D. Henry z Cincinnati Ohio, v panelu byli Valentin Fuster z Mount Sinai Hospital v New Yorku, Renu Virmani z George Washington University a Mamas A. Mamas z Keele University (u Newcastle-under-Lyme, UK).

$\checkmark$ první přednášce Sanjum S. Sethi z New York Presbyterian/Columbian University hovoril o trombotických komplikacích COVID: koagulopatie a trombofilie je častá u nemocných s COVID-19, rizikové faktory jsou předchozí kardiovaskulární onemocnění, imunitní aktivace, šok, metabolické poruchy, koagulopatie, imobilita. Kardiovaskulární komplikace se projevují jako arytmie, myokarditida, akutní koronární syndrom, kardiogenní šok, srdeční selhání. Sanjum S. Sethi upozornil ve své přednášce na práci Maximiliana Ackermanna z Wuppertalu, který $\checkmark$ patologicko-histologické studii devíti pacientů, kteří zemřeli na COVID-19, ukázal, že tito vykazovali těžké endoteliální poškození spojené

Obr. 1. Panel bloku Interventional Cardiology in the era of COVID-19, zprava nahore predsedajici Sahil A. Parikh z Columbia Presbyterian New York city, Valentin Fuster z Mount Sinai Hospital v New Yorku, Renu Virmani z George Washington University a dole zprava spolupredsedající Timothy D. Henry z Cincinnati Ohio a Mamas A. Mamas z Keele University, UK

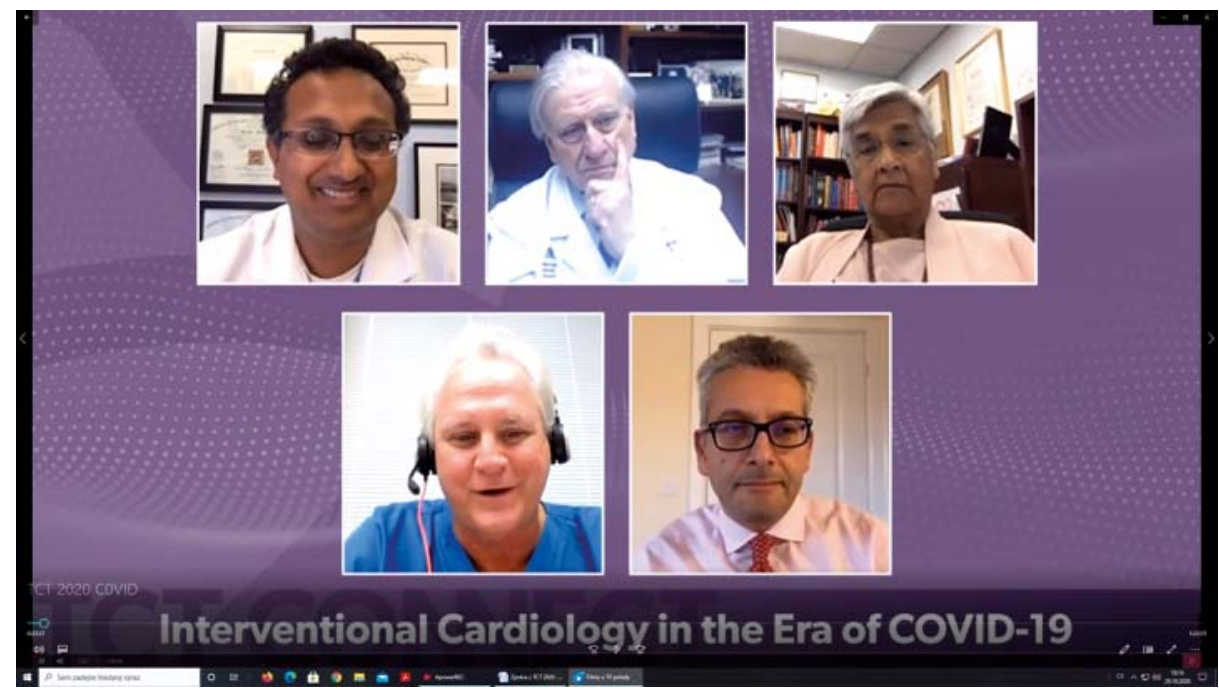

Obr. 2. Giulio Guagliumi z Bergama prezentuje patologicko-anatomické a histologické nálezy na srdci a plicích u nemocných s COVID-19

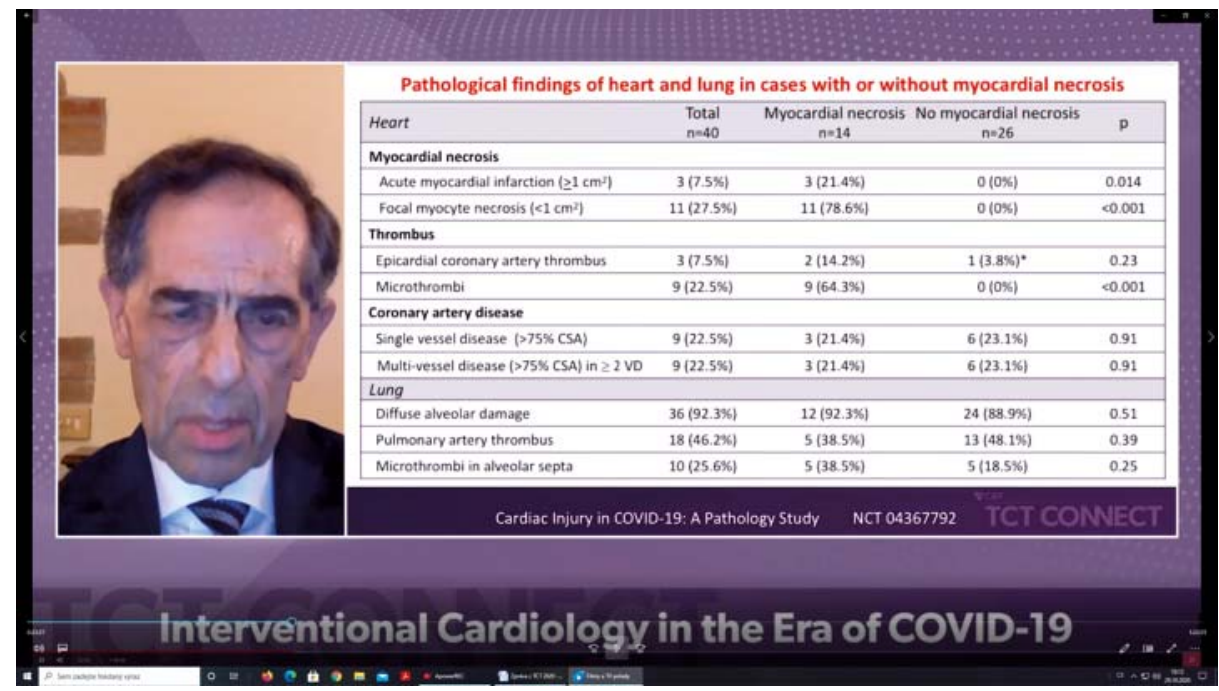

s prítomností intracelulárního viru a narušením buněčných membrán. Histologická analýza plicních cév u pacientů s COVID-19 ukázala rozsáh- lou trombózu s mikroangiopatií. Alveolární kapilární mikrotromby byly $9 \times$ častější u pacientů s COVID-19 ve srovnání s nemocnými s chřipkou.

KORESPONDENČNÍ ADRESA AUTORA:

prof. MUDr. Jan F. Vojáček, DrSc., FESC, FACC, janvojacek@seznam.cz

1. interní kardioangiologická klinika LF UK a FN Hradec Králové, Sokolská 581, 50005 Hradec Králové

Cit. zkr: Interv Akut Kardiol 2020; 19(4): 245-246 
Obr. 3. Anthony H. Gershlick z University Hospital v Leicesteru, UK, prezentuje průběžné výsledky z The Global Multi-Centre Prospective COVID-ACS Registry

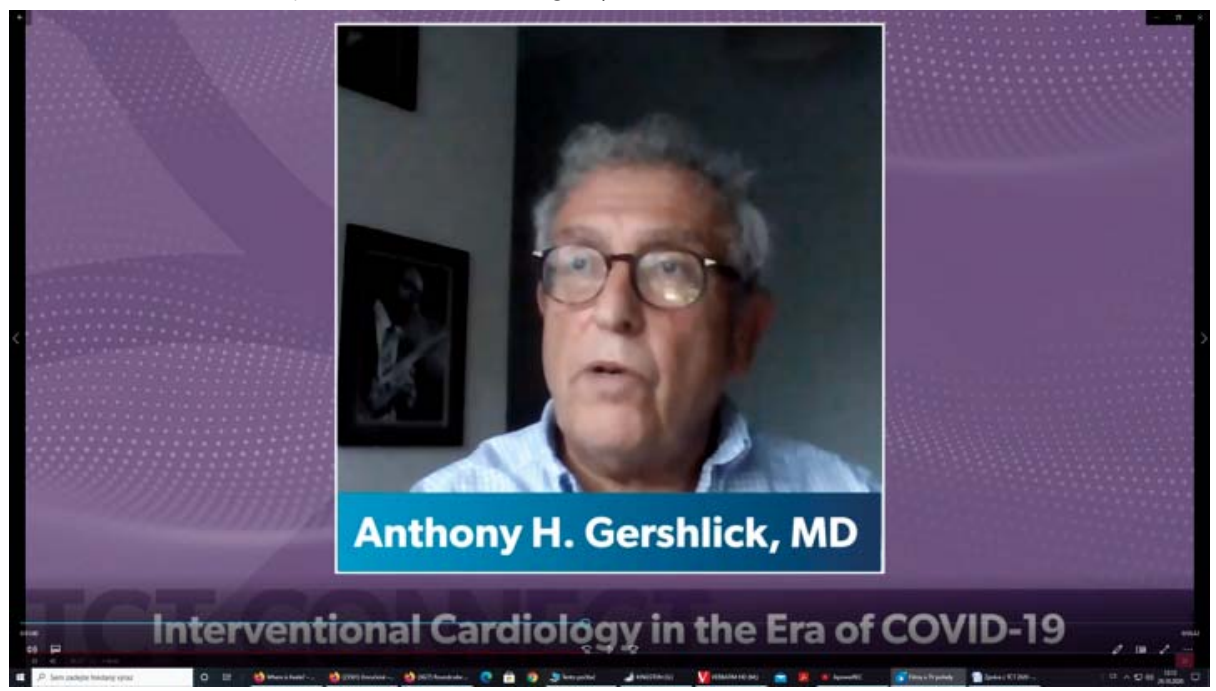

Dále uváděl studii Kloka et al. se 184 nemocnými přijatými na JIP, z nichž všichni dostávali NMH, trombotické komplikace mělo $31 \%$, z toho 25 mělo plicní embolii, 3 žilní trombózu a 3 arteriální trombózu - všichni klinicky mozkovou cévní príhodu, podobná čísla uvádí Poissy a kolegové z Francie (20,6\% nemocných během 6 dní pobytu na JIP, z nichž $90 \%$ mělo profylaktickou dávku heparinu) a poukazují na řádově vyšší výskyt ve srovnánís pacienty léčenými v minulých letech pro komplikace při chřipce.

Sanjum S. Sethi dále upozornil na významně vyšší mortalitu a vyšší výskyt krvácivých komplikací nemocných s plicní embolií při COVID-19 v historickém srovnání s nemocnými bez COVID-19. Probíhá několik randomizovaných studií hodnotících možnosti antikoagulační léčby u těchto nemocných.

Ve druhé přednášce patolog Giulio Guagliumi zBergama se spoluautory z Cardiovascular Pathologic Institute, z Gaithersburgu, Maryland (jde o predměstí Washingtonu těsně za Bethesdou a Chevy (hase), ukázal, že zvýšení troponinu je časté u nemocných hospitalizovaných s COVID-19, prodlužuje hospitalizaci a významně zvyšuje mortalitu. Prezentoval kazuistiku mladé nemocné s bilaterální pneumonií, ST elevacemi, šokovým stavem s těžkou poruchou funkce levé komory a normálním koronarografickým nálezem, patologicko-anatomicky mnohočetné okrsky patchy myokardiální nekrózy, mírná zánětlivá infiltrace a hlavním nálezem byly mnohočetné koronární mikrotromby, složené především z destiček a fibrinu, podobné tromby byly nalezeny v plicních kapilárách a v kapilárách ledvin, současně nalezli lokálně vysokou koncentraci interleukinu 6 a terminální produkty aktivace komplementu.

Velká část nemocných s projevy akutního koronárního syndromu při COVID-19 s perzistujícími ST elevacemi nemá epikardiální trombózu, ale koronární mikrotromby (ve studii Giulio Guagliumi z Bergama byl epikardiální trombus u 14,2 \% nemocných s prokázanou nekrózou myokardu, intrakoronární mikrotrombóza byla u 64,3\% nemocných, současně byl vysoký výskyt nálezu trombů v plicnici a plicních kapilárách), lokálně v histologických vzorcích SARSCoV-2 RT PCR byla pozitivní v plicích u 92,7\% oproti pozitivitě v srdci jen u 22,5\%. Byla diskutována otázka antikoagulační či trombolytické léčby bez jednoznačného závěru. U těchto nemocných je rovněž vysoký výskyt kardiogenního šoku s vysokou mortalitou. Renu Virmani zdůraznila absenci myokarditidy u těchto nemocných a Timothy D. Henry tu skutečnost, že i nemocní s tromby v epikardiálních tepnách rovněž mají difuzní mikrovaskulární mikrotromby a Renu Virmani připomněla spíše nález fibrinu než destičkových agregátů u těchto osob.

Ve třetí velmi dobře hodnocené přednášce Anthony H. Gershlick z University Hospital v Leicesteru, UK, prezentoval průběžné výsledky z The Global Multi-Centre Prospective COVIDACS Registry. V období od 1. března do 31. srpna 2020 bylo zařazeno 316 nemocných z 85 center s COVID-19 a současně s akutním koronárním syndromem a autoři výsledky porovnali s dvěmi národními „pre-covid” databázemi (BCIS STEMI data a MINAP N-STEMI data). Hospitalizační mortalita u nemocných s COVID-19 a současně s akutním koronárním syndromem byla 22,9\%, srdeční selhání se vyskytlo u 23,6 \%, krvácení BARC 3-5 u 2,8 \%, kardiogenní šok byl u 20,1 \% a medián pobytu $v$ nemocnici 6,6 dne. COVID pacienti byli mladší, měli častěji hypertenzi, diabetes, předchozí PCl a chronické onemocnění ledvin. Přicházeli výrazně později, měli významně méně často radiální prístup a byli častěji ventilováni, častěji měli oběhovou podporu a ECMO. Ve srovnání s „pre-covid“ se doba symptoms-door zdvojnásobila, door-balloon stoupla o 46 minut, mortalita byla čtyřnásobná Podobná situace byla i u NSTEMI nemocných.

$\checkmark$ dalších zajímavých sděleních Marco Antona ze San Raffaele Scientific Institute Milano, Itálie hovořil o optické koherenční tomografii k posouzení mikrovaskulární plicní trombózy nemocných s COVID-19 a Robert A. Lemos z Nemocnice Alberta Einsteina, Sao Paulo, Brazílie o robotické asistované PCI u nemocných s COVID-19, jakožto strategii ke snížení rizika kontaminace personálu.

Podpořeno projektem Progres Q40/03. 